\title{
Uptake of Uranium by Lettuce (Lactuca sativa L.) in Natural Uranium Contaminated Soils in Order to Assess Chemical Risk for Consumers
}

\author{
O. Neves • M. M. Abreu • E. M. Vicente
}

Received: 18 December 2007 / Accepted: 27 April 2008 / Published online: 17 June 2008

(C) Springer Science + Business Media B.V. 2008

\begin{abstract}
Uranium mining activity in Cunha Baixa (Portugal) village has left a legacy of polluted soils and irrigation water. A controlled field experiment was conducted with lettuce (Lactuca sativa L.) in an agricultural area nearby the abandoned mine in order to evaluate uranium uptake and distribution in roots and leaves as well as ascertain levels of uranium intake by the local inhabitants from plant consuming. Two soils with different average uranium content (38 and $106 \mathrm{mg} / \mathrm{kg}$ ) were irrigated with non-contaminated and uranium contaminated water $(<20$ and $>100 \mu \mathrm{g} / \mathrm{l})$. A non-contaminated soil irrigated with local tap water $(<1 \mu \mathrm{g} / \mathrm{l}$ uranium) was also used as a control. Uranium in lettuce tissues was positively correlated with soil uranium content, but non-significant differences were obtained from contaminated soils irrigated with differ-
\end{abstract}

O. Neves $(\bowtie) \cdot$ E. M. Vicente

Centro de Petrologia e Geoquímica,

Instituto Superior Técnico,

Universidade Técnica de Lisboa (TULisbon),

Av. Rovisco Pais,

1049-001 Lisboa, Portugal

e-mail: orquidia.neves@ist.utl.pt

M. M. Abreu

Departamento de Ciências do Ambiente,

Instituto Superior de Agronomia,

Universidade Técnica de Lisboa (TULisbon),

Tapada da Ajuda,

1349-017 Lisboa, Portugal

e-mail: manuelaabreu@isa.utl.pt ent water quality. Uranium in plants (dry weight) growing in contaminated soils ranged from 0.95 to $6 \mathrm{mg} / \mathrm{kg}$ in roots and 0.32 to $2.6 \mathrm{mg} / \mathrm{kg}$ in leaves. Lettuce bioconcentration is more related to available uranium species in water than to its uranium concentration. Translocated uranium to lettuce leaves corresponds to $30 \%$ of the uranium uptake whatever the soil or irrigation water quality. A maximum uranium daily intake of 0.06 to $0.12 \mu \mathrm{g} / \mathrm{kg}$ bodyweight day was estimated for an adult assuming 30 to $60 \mathrm{~g}$ /day of lettuce is consumed. Although this value accounts for only $10 \%$ to $20 \%$ of the recommended Tolerable Daily Intake for ingested uranium, it still provides an additional source of the element in the local inhabitants' diet.

Keywords Uranium - Lettuce (Lactuca sativa L.) . Bioconcentration coefficients · Uptake ·

Translocation - Contaminated irrigation water .

Food safety · Cunha Baixa (Portugal)

\section{Introduction}

Uranium (U) is an important natural resource and therefore subject to intensive mining since ancient times (e.g. for colour glass) but its main modern use is in the nuclear power industry. The release of $U$ to the environment represents a potential risk of chemical and radiological toxicity to human health. Since it is found almost everywhere in the Earth's crust in the 
form of more than 200 minerals, corresponding concentrations of $U$ are also found in food of vegetal and animal origin and in groundwater, surface and drinking waters. It enters water supplies via leaching from natural sources (e.g. granites), from anthropogenic activities such as mining operations, nuclear industry, disposal of industrial and medical wastes and from the use of phosphate fertilizers in agriculture (Schnug et al. 2005). The dangers arising from the biochemical toxicity of $U$ as a heavy metal are considered to be about six orders of magnitude higher than those from its radioactivity; compared to other heavy metals its chemical toxicity lies between mercury and nickel (Schnug et al. 2005). Uranium in soil does not often present a radiological hazard to humans, but toxicity to plants could lead to prescribe cleanup and assessment criteria, for industrial activities (Sheppard et al. 1992). Plants growing in mineralised areas were reported to contain up to 100 times more $\mathrm{U}$ compared to plants of another areas (Alloway 1990).

The human body contains approximately $56 \mu \mathrm{g}$ of $\mathrm{U} ; 32 \mu \mathrm{g}(56 \%)$ in the skeleton, $11 \mu \mathrm{g}$ in muscle tissue, $9 \mu \mathrm{g}$ in fat, $2 \mu \mathrm{g}$ in blood and less than $1 \mu \mathrm{g}$ in the lungs, liver and kidneys (Fisenne et al. 1988). Kidneys are considered to be the most sensitive target organ for chemical toxicity of $U$ and long-term ingestion of the element by humans leads to progressive kidney injury. Uranium in the human body is derived mostly from $U$ in food, especially from vegetables, and cereals (Fisenne et al. 1987). Concentrations of $1-15 \mu \mathrm{g} / \mathrm{kg}$ fresh weight have been detected in these products and in some fish species, thus making a noteworthy contribution to $U$ ingestion (Fisenne et al. 1987). The daily intake of $U$ is estimated to be $1-2 \mu \mathrm{g}$ in food and $1.5 \mu \mathrm{g}$ in water consumed (ATSDR 1999). Higher intake levels of 13-18 $\mu \mathrm{g}$ /day have been reported from uranium mining regions (Wrenn et al. 1985). Taking in account common safety factors, the World Health Organization (WHO) estimates a Tolerable Daily Intake (TDI) of $0.6 \mu \mathrm{g} / \mathrm{kg}$ bodyweight day (WHO 2004) and recommends that a $U$ concentration of $0.3 \mu \mathrm{g} / \mathrm{g}$ in the kidneys (WHO 2001) should not be exceeded.

Data on the levels of $U$ in food grown in contaminated areas is limited (ATSDR 1999). Much information about $\mathrm{U}$ behaviour in soil and plant uptake can be obtained from studies of models in laboratory, conducted using experimentally contaminated soil or prepared solutions. Although these experiments are essential to this type of studies, they often can not exactly simulate natural environmental conditions, so it is difficult to predict what will happen in a natural setting. Uranium behaviour in soils is controlled by actions and interactions between physico-chemical (speciation in solution and binding with mineral/organic particles) and biological processes (soil invertebrates, root activity, microorganisms activities, etc...) that also determine its bioavailability (Laroche et al. 2005). Some studies report that a high bioavailable fraction of the element in soils can cause hormesis, decrease yield crop or toxicity (Gulati et al. 1980; Meyer et al. 1998; Shahandeh and Hossner 2002). The information on the U phytotoxicity is yet contradictory; levels as low as $5 \mathrm{mg} / \mathrm{kg}$ in soil have been considered as toxic, whereas many studies reported absence of toxicity at U levels 100 to 1,000 fold higher (Sheppard et al. 1992). It is generally believed that $U$ is not an essential element to plants and generally observed that plants vary greatly in their $U$ uptake capacities (Duquène et al. 2006).

Since 1907 and until 2001, Portugal's Beiras region has been as important uranium-mining district. The intensive former mining activities produced large quantities of waste-rocks that in the absence of any reclamation are still release toxic elements into the surrounding environment. This is the case of the Cunha Baixa uranium mine (Fig. 1), one of the Portuguese mine areas classified as requiring priority intervention (Magno 2001; Silveira 2001). Environmental contamination has been a concern for Cunha Baixa's inhabitants due to uranium mining activities developed there for more than 20 years (1970-1993). Previous environmental studies have identified acid drainage problems and shown that contamination of local shallow groundwater, especially by $\mathrm{U}, \mathrm{Al}, \mathrm{Mn}$ and sulphate, still occurs even though the mine activity ceased in 1993 (Neves 2002; Santos Oliveira et al. 2005; Neves et al. 2005; Neves and Matias 2008). The water of some private wells located near the mine site was most affected and nevertheless has been used by the inhabitants for farmland irrigation. In such conditions chemical and radioactive contaminants may be incorporated into soils and plants. Contaminants in soil and plants may be ingested by farm animals or taken up into the root/shoot system of edible plants and be consumed by humans, so a risk assessment was needed to address concerns expressed by local farmers. Different kinds of crops and foodstuffs are cultivated during the year in the Cunha 
Fig. 1 Geographical location of the Cunha Baixa village and uranium mine as well as surrounding agricultural zones with experimental soils location

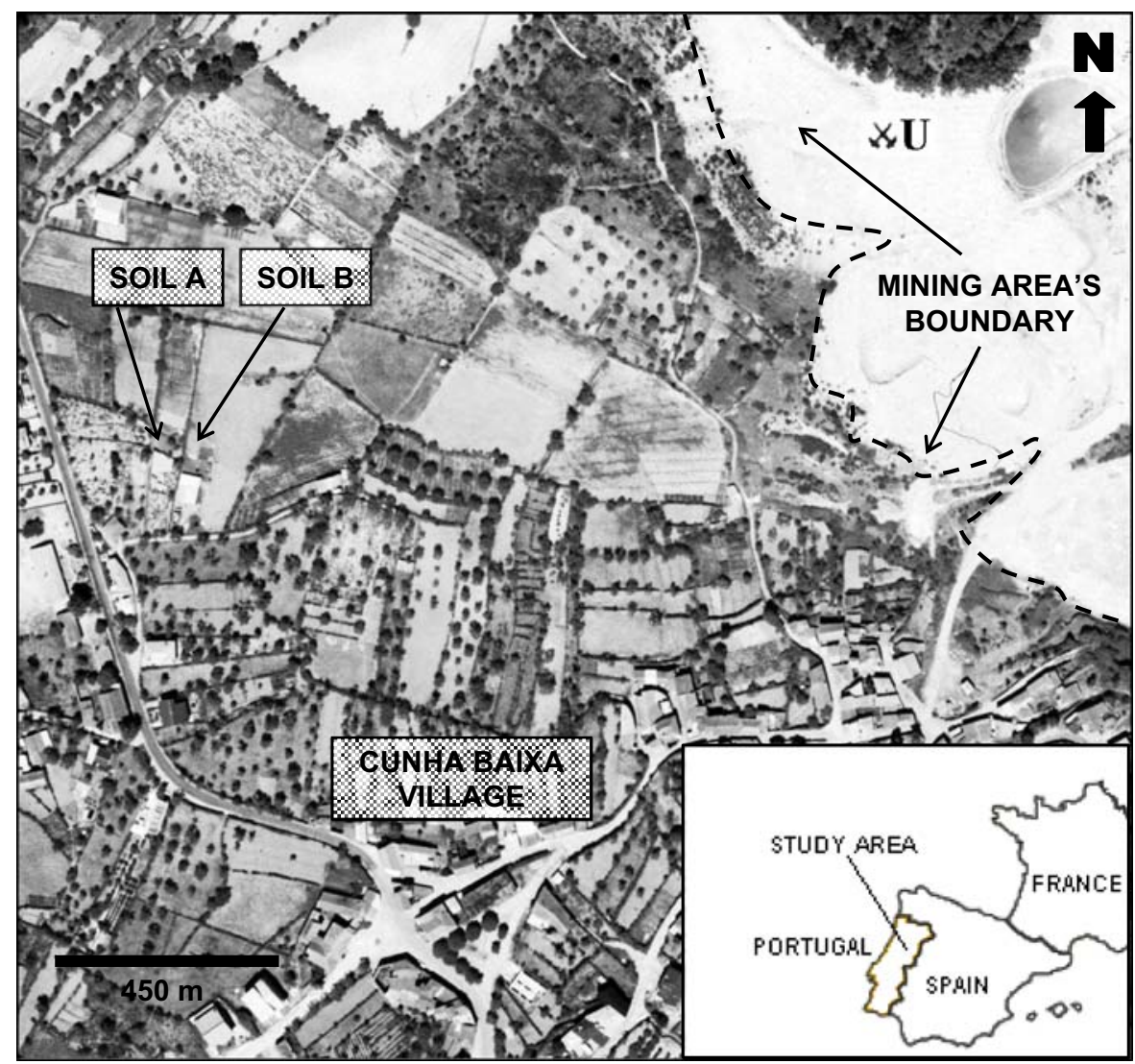

Baixa farmlands, but very little is known about its metal or radiological contents.

The aim of the present study was to determine sitespecific $U$ uptake from soil and irrigation water by lettuce (Lactuca sativa L.) in an experimental agricultural area nearby Cunha Baixa mine site in order to evaluate the uranium accumulation and translocation between edible and non-edible plant parts. Another goal was to evaluate the levels of ingested uranium from lettuce in order to assess chemical risk for the local inhabitants, as it is a vegetable consumed by inhabitants from spring to autumn.

\section{Materials and Methods}

\subsection{Study Area}

The Cunha Baixa village site $\left(40^{\circ} 34^{\prime} 11 \mathrm{~N}\right.$ latitude and $7^{\circ} 45^{\prime} 24 \mathrm{~W}$ longitude) and abandoned mine are located in the Centre of Portugal (Mangualde, Viseu district) granite countryside (Fig. 1). Underground and open pit works and later acid leaching processes were used to recover uranium from the secondary phosphates ore. A more detailed description of Cunha Baixa mining activities is presented elsewhere (Santos Oliveira and Ávila 2001; Neves and Matias 2008). The mine area is bordered on the north to southwest side by agricultural land that produce crops (maize, potatoes, cabbages, beans, onions, carrots, tomatoes, lettuces, spinach) which are used as animal feed or in local inhabitant's diet. The climate of the region is mild, with summer extending from June to September (dry season), while winter ranges from December to March/April (wet season). The annual temperature ranges from $5^{\circ} \mathrm{C}$ to $25^{\circ} \mathrm{C}$ and $70 \%$ of the total precipitation (average rainfall between $1,100-1,400 \mathrm{~mm}$ ) occurs from November/December to March/April.

\subsection{Soil, Plant and Water Sampling}

Controlled field experiments were carried out between the beginning of October and the end of November 2005, in two soils (Soils A and B) located in the 
agricultural area nearby the abandoned uranium mine of Cunha Baixa (Fig. 1). Soils of the study area are classified as Cambisols (Carta de Solos 1978) developed on medium to coarse-grained muscovite and biotitic granite rock. During the field experiment the mean precipitation was $62.2 \mathrm{~mm}$ in October $(78 \%$ of total precipitation during the last 10 days of the month) and $73.8 \mathrm{~mm}$ and November (regularly distributed), and the mean temperature was $12.28^{\circ} \mathrm{C}\left(15.77^{\circ} \mathrm{C}\right.$ in October and $8.80^{\circ} \mathrm{C}$ in November; IM 2007).

The soils selected on the basis of the previous work developed by Neves (2002) are located $50 \mathrm{~m}$ apart from each other in different local kitchen gardens. In both soils, the experimental area with a total of $40 \mathrm{~m}^{2}$, was divided in two plots $(3.4 \times 5 \mathrm{~m}$ with a buffer of $1.2 \mathrm{~m}$ between adjacent plots) and each plot was subdivided in four replicates $(0.5 \times 5 \mathrm{~m}$ each and with a buffer of $0.4 \mathrm{~m}$ between them). One plot was irrigated with uranium-contaminated water and the other with non-contaminated water.

A soil developed under granite rock from the Sintra region (Lisbon) and not contaminated with uranium was used as the control (Soil C). This soil was chosen as the soils developed on granite rocks from Beiras region present high uranium geochemical background $(12 \mathrm{mg} / \mathrm{kg}$ for alluvial soils; Santos Oliveira et al. 2005). Soil C was placed in 16 plastic containers (internal draining asserted) and irrigated with local tap water.

A representative composite sample of the topsoil layer $(0-20 \mathrm{~cm})$ was collected at each replicate (in 15 sampling points) before lettuce plantation and after harvest time.

A total of 448 lettuces were planted (10 days of growth) in the four soil plots with a plant density of 28 plants per replicate (two plants apart $25-30 \mathrm{~cm}$ on 14 points). Thirty-two lettuces were planted in plastic containers (two plants in each container). At the end of the growth period ( 60 days after transplanting), all edible (leaves) and non-edible (roots) plant production was collected.

The waters with different uranium concentrations were pumped from private wells, which have been used by local farmers for irrigation of the selected soils. Irrigation water samples were collected during the field experiments. Due to meteorological conditions (rainy weather) during the experiment (on average a total of $222.40 \mathrm{~mm}$ from October 21 to November 30 ) the lettuce plants were watered only seven times during the first month of growth with a total of $36 \mathrm{l} / \mathrm{m}^{2}$.

To ensure the normal growth and development of lettuce plants, $227 \mathrm{~g} / \mathrm{m}^{2}$ of dissolved Nitromagnesium 20.5 fertilizer $\left(20.5 \% N_{\text {total }}, 10.25 \% N_{\text {nitric }}, 10.25 \%\right.$ $N_{\text {ammonium }}, 12 \% \mathrm{CaO}$ and $6 \% \mathrm{MgO}$ ) was applied to soils 20 days after transplantation.

The selection of crop variety (Lactuca sativa L., cv. Marady), the use of fertilizers, frequency and amount of irrigation treatments were done according to local agricultural practices.

\subsection{Soil, Plant and Water Analysis}

Soil samples were air-dried, sieved through $2 \mathrm{~mm}$ and analysed for: particle size distribution by sieving and sedimentation after sodium hexametaphosphate dispersion; $\mathrm{pH}$ in a water suspension (1:2.5 soil/water); salinity (electrical conductivity of extract saturation); cation exchange capacity (CEC) by $1 \mathrm{M}$ ammonium acetate at pH 7 (Póvoas and Barral 1992); total organic carbon (TOC) by Walkley and Black (1934); extractable $\mathrm{P}$ and $\mathrm{K}$ by Egner-Riehm (Egner et al. 1960); N mineral by Keeney and Nelson (1982); total and available uranium after acid digestion (Code ultratrace 4, Actlabs Laboratory, Canada) and $1 \mathrm{M}$ ammonium acetate extraction (Schollenberger and Simon 1945), respectively.

After harvest, plants were carefully washed with tap water in situ for soil particles removal and the aerial part separated from roots. At the laboratory, plant material was washed with distilled water, centrifuged and weighed before and after its drying $\left(40^{\circ} \mathrm{C}\right)$; dried plants were then ground for elemental analysis. The analytical process involved ashing and digestion with $\mathrm{HNO}_{3}$ and $\mathrm{H}_{2} \mathrm{O}_{2}$ (Code 2B, Actlabs Laboratory, Canada).

Temperature, $\mathrm{pH}$, Eh and EC of water samples were measured in situ using portable probes (WRW, Germany). Total alkalinity determinations (Method 2320B, Arnold et al. 1992) were performed before samples filtration. The filtered samples without or with $\mathrm{HNO}_{3}$ acidification at $\mathrm{pH}<2$ were stored under cool conditions $\left(4^{\circ} \mathrm{C}\right)$ until analysis. Ion sulphate by ion chromatography and fluoride and total $\mathrm{P}$ analysis by spectrophotometry were also performed.

Elemental analyses of extracting solutions (soil and plant samples) were performed by ICP-MS and ICPOES (water samples) at Actlabs Laboratory, Canada. 


\subsection{Data Analysis}

The results for each soil plot were expressed as an average of four replicates. However, for lettuces grown in soil $\mathrm{C}$, as the biomass was low, it was necessary to combine the yield of the two replicates each. The experimental data were subject to an analysis of variance (ANOVA) using STATISTICA 6.0 for Windows, and the averages were compared by the Tukey HDS test at the 5\% level of significance. Pearson coefficient considering significant differences at a 5\% level was used for data correlation evaluation.

Aqueous geochemical modelling using the computer program Web-PHREEQC (Parkhurst 1995) with WATEQ4 thermodynamic database was performed to calculate predominant uranium species in irrigation water.

The soil-plant transfer factor used in evaluation studies on the impact of releases of radionuclides into the environment that represents the capacity of a species to accumulate an element was defined as:

Concentration Ratio $(\mathrm{CR})=[$ edible part $] /[$ total soil $]$

\section{(IAEA 1994)}

The Soil-Bioconcentration Coefficient (S-BC) that reflects the plant capacity to absorb the element from the soil when it occurs in an available form, determined after soil chemical extraction using an appropriate solution (Nriagu 1991; Abreu et al. 2008), was calculated as follows:

$$
\begin{aligned}
& \mathrm{BC}_{\text {plant } / \text { soil }}=[\text { root }+ \text { leaf }] /\left[\text { available soil fraction, extracted byNH} \mathrm{NH}_{4}-\text { acetate }\right] \\
& \mathrm{BC}_{\text {leaf } / \text { soil }}=[\text { leaf }] /\left[\text { available soil fraction, extracted by } \mathrm{NH}_{4}-\text { acetate }\right]
\end{aligned}
$$

The Water-Bioconcentration Coefficient (W-BC) which reflect the plant capacity to absorb the element from the irrigation water was defined as:

$\mathrm{BC}_{\text {plant }} /$ water $=[$ root + leaf $] /[$ dissolved in irrigation water $]$ $\mathrm{BC}_{\text {leaf }} /$ water $=[$ leaf $] /[$ dissolved in irrigation water $]$
The Translocation Coefficient (TC), used for evaluating the element translocation plant capacity for the edible part was defined as:

$\mathrm{TC}=[$ leaf $] /[$ root + leaf $]$

The uranium concentration in lettuce was converted to a fresh mass basis for ingestion calculations using sitespecific wet/dry ratios for plants from each soil replicate.

The daily intake from ingestion $\left(\mathrm{DI}_{\mathrm{ing}}\right)$ through lettuces was calculated as follows:

$$
\begin{aligned}
\mathrm{DI}_{\text {ing }}(\mu \mathrm{g} / \mathrm{kg} \text { bodyweight day })= & \text { concentration of uranium in vegetable }(\mu \mathrm{g} / \mathrm{g} \text { fresh weigh }) \\
& \times \text { mean vegetation consumption }(\mathrm{g} / \text { person day }) / \text { reference bodyweight }(\mathrm{kg})
\end{aligned}
$$

\section{Results and Discussion}

\subsection{Water Irrigation and Soils}

The non-contaminated water used in the field experiments (Table 1) belongs to a mixed $\mathrm{Na}-\mathrm{Ca} / \mathrm{Cl}-\mathrm{HCO}_{3}$ type water and represents shallow groundwater water not affected by local uranium-mining activities (Neves 2002; Neves et al. 2005; Neves and Matias
2008). The non-contaminated and local tap waters presented low U content; the latter did not exceed the safe level of $15 \mu \mathrm{g} / \mathrm{l}$ provisional guideline considered by WHO (2004) for drinking-water quality. The contaminated water belongs to the $\mathrm{Ca} / \mathrm{Mg}-\mathrm{SO}_{4}$ type and should not be used by farmers for irrigation. During the experiments this water presented $U$ concentrations 9 to 12 -fold higher than the trigger value (Table 1) established in Australia and New 
Table 1 Water irrigation characteristics

\begin{tabular}{lllllll}
\hline Irrigation water & $\mathrm{pH}$ & $\mathrm{EC} \mathrm{mS/cm}$ & $\mathrm{SO}_{4}^{-2}(\mathrm{mg} / \mathrm{l})$ & $\mathrm{Al}(\mathrm{mg} / \mathrm{l})$ & $\mathrm{Mn}(\mathrm{mg} / \mathrm{l})$ & $\mathrm{U}(\mu \mathrm{g} / \mathrm{l})$ \\
\hline Tap water & $7.7-8.7$ & $0.06-0.14$ & $17-18$ & $0.09-0.2$ & $<0.001$ & $0.5-1.4$ \\
Non-contaminated & $6.1-6.2$ & $0.16-0.27$ & $32-49$ & $0.16-0.20$ & 0.03 & $19-20$ \\
Contaminated & $4.3-4.4$ & $1.68-1.712$ & $923-1,072$ & $7.9-8.1$ & $3.9-4.1$ & $988-1,140$ \\
MAV & $5.0-9.0$ & 1.0 & 575 & 5 & 0.2 & $100^{\mathrm{a}}$ \\
MRV & $6.5-8.4$ & & & 20 & 10 \\
\hline
\end{tabular}

$M A V$ (maximum allowable value) and $M R V$ (maximum recommended value) established by Portuguese law (DL 236/98)

${ }^{a}$ Trigger value established in Australia and New Zealand for irrigation (ANZECC 2000)

Zealand for short-term irrigation (ANZECC 2000). The values for $\mathrm{pH}, \mathrm{EC}, \mathrm{SO}_{4}^{-2}, \mathrm{Al}$ and $\mathrm{Mn}$ also exceed the Maximum Allowable Value (MAV) established by Portuguese law (Table 1) for this purpose. The salinity of this water $(>1.5 \mathrm{mS} / \mathrm{cm})$ presents a high salinity hazard for soil so detrimental effects on sensitive crops could be expected (IWQC 1997), if careful management practices were not considered. The fluorine and total dissolved phosphate were generally lower in all waters $(0.07$ to $0.69 \mathrm{mg} / \mathrm{l}$ and $<0.05$ to $0.1 \mathrm{mg} / \mathrm{l}$, respectively).

Uranium speciation, which is related to soil and water properties, namely $\mathrm{pH}$ and presence or absence of dissolved inorganic ligands, could be a factor influencing uranium uptake by the plants. Uranium forms complexes with sulphate and phosphate as well as with carbonate and hydroxide ions, which increase the total solubility of uranium (Langmuir 1978). Uranium chemical speciation calculations showed that in local tap water the $\mathrm{UO}_{2}(\mathrm{OH})^{3-}$ was the predominant species
$(>99 \%)$ whereas $\mathrm{UO}_{2}\left(\mathrm{HPO}_{4}\right)_{2}^{2-}(>99 \%)$ was dominant in the non-contaminated water. Uranium species as $\mathrm{UO}_{2} \mathrm{SO}_{4}(>48 \%)$ followed by $\mathrm{UO}_{2}\left(\mathrm{HPO}_{4}\right)_{2}^{2-}(<28 \%)$, $\mathrm{UO}_{2}^{2+}(<18 \%)$ and $\mathrm{UO}_{2}\left(\mathrm{SO}_{4}\right)_{2}^{2-}(<3.5 \%)$ dominate in contaminated irrigation water. The high $\mathrm{SO}_{4}^{2-}$ levels in contaminated water explain why $\mathrm{UO}_{2} \mathrm{SO}_{4}$ was the dominant species at low water $\mathrm{pH}(<5)$.

At the beginning of the field experiments, the topsoil's layer presents physic and chemical characteristics given in Table 2. Soils were sandy-loam (soils A and $\mathrm{B}$ ) and loam (soil $\mathrm{C})$, acidic $(\mathrm{pH}<5.5)$ with low salinity $(<1,000 \mu \mathrm{S} / \mathrm{cm})$ as well as $\mathrm{CEC}\left(<12 \mathrm{cmol}_{\mathrm{C}} / \mathrm{kg}\right)$ and poor in TOC $(<16 \mathrm{~g} / \mathrm{kg})$. Comparing both soils $\mathrm{A}$ and $\mathrm{B}$, the extractable $\mathrm{K}$ and $\mathrm{P}$ content were similar and adequate for lettuce nutrition, but the $N_{\text {mineral }}$ was lower in soil A. According to INIA (2000) $120 \mathrm{mg} \mathrm{K} / \mathrm{kg}$ soil, 26-33 mg P/kg soil and 35-45 mg N/kg soil are considered the optimum values for lettuce growth. All these nutrients were also in deficit in soil $\mathrm{C}$ at the beginning of the field

Table 2 Physic and chemical characteristics of soils A, B and C collected before lettuce planting

\begin{tabular}{lccc}
\hline & Soil A & Soil B & Soil C \\
\hline Particle size distribution & & & \\
Sand $(\mathrm{g} / \mathrm{kg})$ & $748.0 \pm 6.8$ & $711.5 \pm 8.7$ & $849.3 \pm 15.8$ \\
Silt $(\mathrm{g} / \mathrm{kg})$ & $145.1 \pm 4.0$ & $163.3 \pm 1.5$ & $86.8 \pm 5.0$ \\
Clay $(\mathrm{g} / \mathrm{kg})$ & $107.7 \pm 3.4$ & $125.2 \pm 12.4$ & $56.5 \pm 4.2$ \\
$\mathrm{pH}\left(\mathrm{H}_{2} \mathrm{O}\right)$ & $5.6 \pm 0.2$ & $5.5 \pm 0.2$ & $5.8 \pm 0.1$ \\
$\mathrm{EC}(\mu \mathrm{S} / \mathrm{cm})$ & $671.5 \pm 68.4$ & $995.7 \pm 81.1$ & $482.2 \pm 14.7$ \\
$\mathrm{CEC}(\mathrm{cmol} / \mathrm{kg})$ & $9.39 \pm 0.46$ & $11.29 \pm 0.43$ & $5.10 \pm 0.17$ \\
TOC $(\mathrm{g} / \mathrm{kg})$ & $14.72 \pm 0.85$ & $10.64 \pm 0.81$ & $10.11 \pm 2.15$ \\
$K_{\text {extractable }}(\mathrm{mg} / \mathrm{kg})$ & $234.58 \pm 75.88$ & $252.11 \pm 23.82$ & $105.6 \pm 1.0$ \\
$P_{\text {extractable }}(\mathrm{mg} / \mathrm{kg})$ & $78.47 \pm 18.04$ & $46.43 \pm 13.67$ & $0.98 \pm 0.22$ \\
$N_{\text {mineral }}(\mathrm{mg} / \mathrm{kg})$ & $21.11 \pm 3.68$ & $41.77 \pm 4.36$ & $7.15 \pm 1.78$ \\
$U_{\text {total }}(\mathrm{mg} / \mathrm{kg})$ & $38.6 \pm 2.6$ & $106.3 \pm 16.9$ & $2.78 \pm 0.80$ \\
$U_{\text {available }}(\mathrm{mg} / \mathrm{kg})$ & $2.81 \pm 0.8$ & $14.5 \pm 3.8$ & $0.04 \pm 0.01$ \\
\hline
\end{tabular}

The values correspond to average $\pm \mathrm{SD}(n=8$ for soil $\mathrm{A}$ and $\mathrm{B}$ and $n=4$ for soil $\mathrm{C}$ ) 
experiments. The total uranium content (average) in soils A and B (38 to $106 \mathrm{mg} / \mathrm{kg}$ ) was considerably higher than those found in literature for normal concentration range $(0.3$ to $11.7 \mathrm{mg} / \mathrm{kg}$; Bleise et al. 2002) as was the case with control soil C. The soil B presented a total $\mathrm{U}$ content threefold higher than soil A. Its proximity to the mining area and irrigation with rich uranium water $(>100 \mu \mathrm{g} / \mathrm{l}$, Table 1$)$ for a long time may be factors that contributed to this enrichment. Amrhein et al. (1993) also reported that in the San Joaquim Valley (USA) the irrigation with uranium water increased the $U$ levels in the upper centimetres of agricultural soils.

The available $\mathrm{U}$ in soils was low and represents, on average, about $7 \%, 14 \%$ and $1.5 \%$ of the total, respectively, in soils $\mathrm{A}, \mathrm{B}$ and $\mathrm{C}$ (Table 2). This can be related to the low clay fraction and organic matter soils content and, as a consequence, a low CEC. In general, organic matter and clay minerals provide negative exchange sites which are expected to increase sorption of positively charged uranium species as free uranyl $\mathrm{UO}_{2}^{2+}$, which predominates under acidic conditions (Langmuir 1978; Ebbs et al. 1998; Laroche et al. 2005). Available U in all soils was significantly correlated to CEC before and after lettuce growth ( $r=0.83$ and $r=0.90$, respectively). The higher available $U$ in soil $B$ could be related to its slightly higher CEC and clay fraction (Table 2) or even to the high $\mathrm{U}$ concentration presented in the soil solution.

At the end of the field experiments, in both soil A and $\mathrm{B}$ irrigated with different water quality, the total and available $U$ concentration did not differ significantly; although, on average and after 2-month of lettuce growth, a small decrease of 1,2 and $4 \%$ on the $U_{\text {available }} / U_{\text {total }}$ concentration ratio on soil C, A and B, respectively, was observed (Fig. 2).

\subsection{Uranium Concentration in Lettuce}

The uranium concentration in lettuce roots and leaves grown in the different soil plots is presented in Fig. 3. The non-edible tissues (roots) had the highest $U$ concentration which agrees with results from other authors that reported for $U$ the following rank: roots > shoot/leaves $>$ fruits/grains (Ribera et al. 1996; Singh 1997; Shahandeh and Hossner 2002; Duquène et al. 2006). In these field experiments, $U$ in lettuce roots was two- to threefold greater than $U$ concentration in
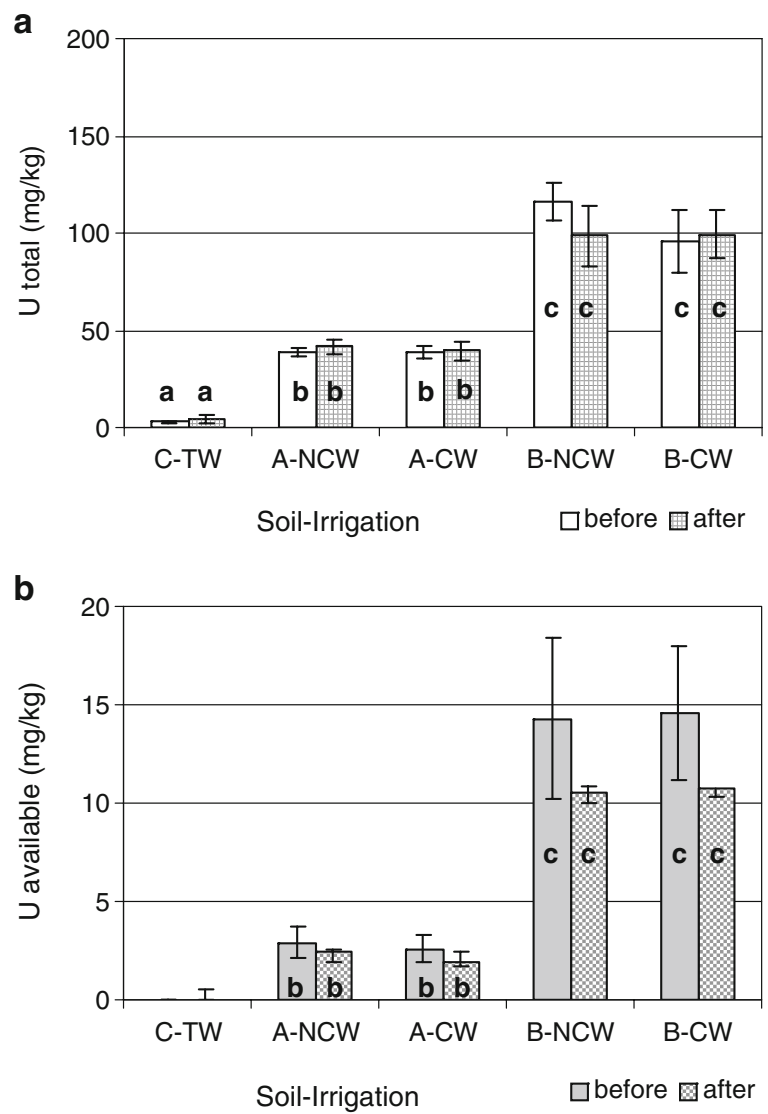

Fig. 2 Total (a) and available (b) uranium concentration on plot soils C, A and B before and after lettuce growth submitted to different irrigation waters ( $T W$ Tap water; $N C W$ noncontaminated water and $C W$ contaminated water). Bars represent SDs of four replicates. Averages for total or available U before or after lettuce growth followed by the same letter are not significantly different by the Tukey test at $p<0.05$

the leaves (Fig. 3). The roots from soil B contain more $\mathrm{U}$ (3.28 to $6 \mathrm{mg} / \mathrm{k}$ dry weight) than roots from soil A (0.95 to $1.67 \mathrm{mg} / \mathrm{kg}$ dry weight) or than roots from soil C ( 0.1 to $0.11 \mathrm{mg} / \mathrm{kg}$ dry weight), which is in accordance with the total and available $U$ of each soil (Table 2).

The same trend was observed for leaves (Fig. 3); lower $\mathrm{U}$ concentration in lettuce leaves from soil $\mathrm{C}$ ( 0.03 to $0.04 \mathrm{mg} / \mathrm{kg}$ dry weight) and higher in lettuce leaves from soil B (1.57 to $2.62 \mathrm{mg} / \mathrm{kg}$ dry weight).

There were significant relationships between $U$ in plant tissues [(root + leaf $)$ dry weight $]$ and the total and available $\mathrm{U}$ in all soils sampled before $(r=0.89$ and $r=0.83$, respectively) or after $(r=0.91$ and $r=$ 0.94 , respectively) plant growth. However, no signif- 


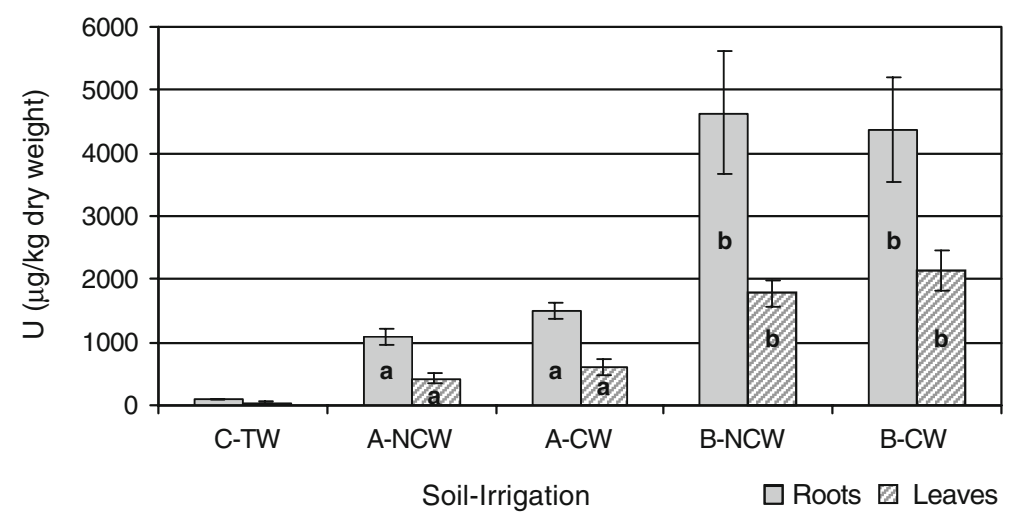

Fig. 3 Uranium concentration in roots and leaves $(\mathrm{mg} / \mathrm{kg}$ dry weight) of lettuce grown on soils $\mathrm{C}, \mathrm{A}$ and $\mathrm{B}$, submitted to different irrigation water (TW Tap water; $N C W$ non-contaminated water and $C W$ contaminated water). Bars represent SDs

icant differences were observed in $U$ concentration in roots or in leaves of lettuce plants grown in soil B or in soil A when irrigated with or without uraniumcontaminated water (Fig. 3). These results are in disagreement with those obtained by Kovalevsky (IAEA 1985); since this author stated that U absorption by plants was, on average, 3,000 times more vigorous from aqueous solutions than from the soil. Despite different study conditions, other authors (Lakshmanan and Venkateswarlu 1988; HakonsonHayes et al. 2002) also observed an increase in the U level in vegetables with the increase of $U$ concentration in the irrigation water.

The effect of water irrigation quality was only verified on the lettuce yield (above-ground biomass); a decrease of $40 \%$ and $50 \%$ was, respectively, observed in plots of soil A and B watered with uranium-contaminated water (Neves and Abreu 2006). This must be due to the lower $\mathrm{pH}$ and the high values of salinity, sulphate, aluminium and manganese determined in uranium-contaminated water (Table 1). In fact, soil parameters as $\mathrm{pH}$ and salinity seem not to be responsible for lettuce yield decrease, as during field experiments soil $\mathrm{pH}$ was within the range of values considered for normal lettuce plants growth (6.0 to 7.0) and soil salinity did not increase or reach the lower limit for lettuce salinity tolerance (1.0 to $3.0 \mathrm{mS} / \mathrm{cm}$; Foth 1990).

Considering the plant's element concentration and lettuce yield only a significant negative correlation was observed with manganese (dry weight) in lettuce leaves growing in both $\mathrm{A}$ and $\mathrm{B}$ soils $(r=-0.95)$. However, visual toxicity symptoms for manganese of four replicates. Averages for roots and leaves followed by the same letter are not significantly different by the Tukey test at $p<0.05$

were not observed and the Mn plant content lies between the limits for deficiency and toxicity (25 and $500 \mathrm{mg} / \mathrm{kg}$ dry weight, respectively; Srivastava and Gupta 1996).

\subsection{Uranium Bioconcentration and Translocation in Lettuce}

Plants remove nutrients from irrigation water and from the readily exchangeable and soluble fractions of the soil. In the studies related to the absorption and $U$ accumulation it was generally observed that there are significant variations in $U$ accumulation between plant species (Shahandeh and Hossner 2002). The ability of the plants to absorb $U$ or to transfer the element within the plant (translocation) was evaluated by absorption coefficients (Table 3 ).

The CRs for lettuce $U$ uptake ranged between 0.011 and 0.023 (Table 3) and fall within generic CR values (between $10^{-2}$ and $10^{-3}$ ) published by IAEA (1994). These values may be used as a first approximation in assessment studies, however, according to IAEA (1994), site-specific deviations of a factor of 10 or more must be expected (overall range of $10^{-1}$ trough $10^{-4}$ ). Sheppard and Evenden (1988) attributed wide-ranging uranium CRs to the dynamic physical, chemical and biological interactions in the plant/soil system. Studies carried out by Sheppard et al. (1989) on uptake of natural radionuclides by field and garden crops, also reported an overall geometric mean CR of 0.013 for uranium. The $\mathrm{CR}$ value of 0.025 calculated by Sheppard et al. (1989) for lettuce growing on soil lysimeters are similar to those 
Table 3 Uranium concentration ratio $(\mathrm{CR}=[$ leaf $] /[$ total soil), Uranium Bioconcentration Coefficients from soil $\left(\mathrm{BC}_{\mathrm{plant}} /\right.$ soil $=$ $[$ root + leaf $] /\left[\right.$ available soil fraction, extracted by $\mathrm{NH}_{4}-$ acetate $]$ and $\mathrm{BC}_{\text {leaf } / \text { soil }}=[$ leaf $] /[$ available soil fraction, extracted by $\mathrm{NH}_{4}-$ acetate]) and Uranium Bioconcentration Coefficients from Water $\left(\mathrm{BC}_{\text {plant } / \text { water }}=[\right.$ root + leaf $] /[\mathrm{U}$ dissolved in water $]$ and $\mathrm{BC}_{\text {leaf } / \text { water }}=[$ leaf $] /[\mathrm{U}$ dissolved in water $]$ ) for lettuce grown in plot soils $\mathrm{C}, \mathrm{A}$ and $\mathrm{B}$ submitted to different irrigation water quality

\begin{tabular}{lllllll}
\hline Soils & Water irrigation & $\mathrm{CR}$ & $\mathrm{BC}_{\text {plant/soil }}$ & $\mathrm{BC}_{\text {leaf } / \text { soil }}$ & $\mathrm{BC}_{\text {plant/water }}$ & $\mathrm{BC}_{\text {leaf } / \text { water }}$ \\
\hline Soil C & Tap water & $0.014 \pm 0.007$ & $3.74 \pm 0.83$ & $0.039 \pm 0.006$ & $152.6 \pm 15.8$ & $41.8 \pm 10.4$ \\
Soil A & Non-contaminated & $0.011 \pm 0.002 \mathrm{a}$ & $0.55 \pm 0.16 \mathrm{a}$ & $0.16 \pm 0.07 \mathrm{a}$ & $79.27 \pm 8.15 \mathrm{a}$ & $22.37 \pm 4.41 \mathrm{a}$ \\
& Contaminated & $0.016 \pm 0.004 \mathrm{ab}$ & $0.83 \pm 0.17 \mathrm{a}$ & $0.23 \pm 0.05 \mathrm{a}$ & $1.97 \pm 0.23 \mathrm{bd}$ & $0.57 \pm 0.12 \mathrm{~b}$ \\
Soil B & Non-contaminated & $0.015 \pm 0.002 \mathrm{ab}$ & $0.48 \pm 0.15 \mathrm{a}$ & $0.13 \pm 0.04 \mathrm{a}$ & $341.0 \pm 61.3 \mathrm{c}$ & $94.72 \pm 10.94 \mathrm{c}$ \\
& Contaminated & $0.023 \pm 0.003 \mathrm{~b}$ & $0.48 \pm 0.16 \mathrm{a}$ & $0.15 \pm 0.04 \mathrm{a}$ & $6.11 \pm 0.98 \mathrm{ad}$ & $2.00 \pm 0.30 \mathrm{~b}$ \\
\hline
\end{tabular}

The values correspond to average $\pm \mathrm{SD}$ ( $n=4$ for soils $\mathrm{A}$ and $\mathrm{B}$ and $n=2$ for soil $\mathrm{C}$ ). Average followed by the same letter in a column are not significantly different by the Tukey HSD test at $p<0.05$

obtained for Cunha Baixa lettuce plants. However, some authors consider that the Bioconcentration Coefficient (BC) reflects, in a more realistic way, the plant capacity to absorb the element from the soil when it occurs in an available form (Nriagu 1991; Abreu et al. 2008). Otherwise an assessment based on the use of CRs may not represent the real situation, as a considerable part of total $U$ is not frequently available for plants. This is the case of the studied soils where the available fraction corresponds to $1.5-$ $14 \%$ of the $U_{\text {total }}$ (Fig. 2). The $\mathrm{NH}_{4}$-acetate solution used in this work seems to be a good extraction solution to evaluate the bioavailable soil $U$ fraction. In fact, Sheppard and Evenden (1992) reported that extraction efficiency of $\mathrm{NH}_{4}$-acetate, tested in 11 uranium amended soils (covering a broad range in soil properties and uranium concentration ranging from background to $10,000 \mathrm{mg} / \mathrm{kg}$ dry soil), was well correlated to the concentration ratios, calculated using the $\mathrm{U}$ concentration in that extraction solution.

The Soil-Bioconcentration Coefficients (S-BCs), used for $U$ absorption evaluation by Cunha Baixa lettuce from soil (Table 3), were calculated (see section 2.3) using the soil available uranium at the beginning of the experiments. The Uranium Bioconcentration Coefficients $\left(\mathrm{BC}_{\text {plant/soil }}\right.$ and $\left.\mathrm{BC}_{\text {leaf/soil }}\right)$ from soils $\mathrm{A}$ and $\mathrm{B}$ exceeded IAEA values by approximately one order of magnitude. However, the S-BCs are not significantly different for soils A and B even when irrigated with different water quality.

The uranium absorption by lettuce from water irrigation, calculated from $\mathrm{BC}_{\text {plant/water }}$ (ranged between 1.63 and 430) and $\mathrm{BC}_{\text {leaf/water }}$ (ranged between 0.37 and 111.72) were higher than the S-BCs $\left(\mathrm{BC}_{\text {plant/soil }}\right.$ and $\mathrm{BC}_{\text {leaf/soil }}$ ) calculated from soil available $\mathrm{U}$ content
(Table 3). These results confirm the trend of a larger variability for water/plant transfer than for soil/plant transfer (Hayes et al. 2000). Based on the abovecalculated coefficients using irrigation water and in lack of phytotoxicity signs, lettuce plants in our experiments can be considered tolerant to high uranium contents in irrigation water. However, for the same soil both W-BCs $\left(\mathrm{BC}_{\text {plant/water }}\right.$ and $\left.\mathrm{BC}_{\text {leaf } / \text { water }}\right)$ were higher in the plot watered with lower uranium concentration, as is the case of soil C (Table 3). Lakshmanan and Venkateswarlu (1988) also observed that the concentration factor for the $\mathrm{U}$ uptake by vegetables decreases with water $U$ increase. The uranium chemical species present in the different irrigation waters might explain these results. According to the work of Ebbs et al. (1998), the free uranyl cation $\left(\mathrm{UO}_{2}^{2+}\right)$, which predominates at $\mathrm{pH}$ of $5.0-5.5$ or less, is the $U$ specie most readily taken up and translocated by plants. The experimental data of Vandenhove et al. (2007) also feature the potential importance of $U$ speciation in explaining the soil-to plant transfer factors; apparently $\mathrm{UO}_{2}^{2+}, \mathrm{UO}_{2} \mathrm{PO}_{4}^{-}$and uranyl carbonate complexes were the $\mathrm{U}$ species being preferentially taken up by ryegrass roots and transferred to the shoots. Moreover, Laroche et al. (2005) observed in hydroponic studies that the presence of ligands in the solution, such as phosphate or hydroxo, did not affect uranium uptake by beans (Phaseolus vulgaris) up to $\mathrm{pH} 7$. In tap water and non-contaminated irrigation water $U$ was present as hydroxide and phosphate complexes ( $>99 \%$ ), respectively, whereas in contaminated water only $52 \%$ of the total uranium was in available ionic species for plant uptake (phosphate and sulphate complexes or free uranyl cation). These results suggest that the absorption of uranium from 
lettuce plants growing in soils with the same uranium concentration was higher when it was irrigated with non-contaminated water. This behaviour explains why the uranium concentrations of tissues (roots and leaves) of lettuce plants grown in the same soil were not significantly different irrespective of the level of irrigation water contamination (Fig. 3).

The Translocation Coefficient (TC) was used for evaluating $U$ transfer within lettuce plant. The TC values, determined from the replicates of lettuce plants grown in soils C $(0.27 \pm 0.04)$, A $(0.28 \pm 0.04)$ and $\mathrm{B}(0.31 \pm 0.04)$ are similar. It should be stated that no significant differences $(p<0.05)$ were found between TC average values in lettuce from soils A and $\mathrm{B}$ irrigated with different water quality. These data show that, on average, $30 \%$ of the lettuce $U$ uptake from soil and water was transferred for the edible part of the plant. This ratio is constant whatever soil and water uranium concentration.

The varying ranges of $U$ concentration in fresh edible part of lettuce grown in the study soils are presented in Fig. 4. The average concentrations (fresh weight) were: $4 \pm 1 \mu \mathrm{g} / \mathrm{kg}$ for soil C, $22 \pm 5 \mu \mathrm{g} / \mathrm{kg}$ for soil A and $100 \pm 20 \mu \mathrm{g} / \mathrm{kg}$ for soil B.

The levels of $\mathrm{U}$ in lettuce grown in soils $\mathrm{A}$ and $\mathrm{B}$ exceeded the mean concentration presented by Schnug et al. (2005) for $U$ in vegetables leaves $(0.5$ to $5 \mu \mathrm{g} / \mathrm{kg}$ fresh weight). Intake of $\mathrm{U}$ trough lettuce consumption by a local inhabitant was assessed based on the mean ingestion lettuces rate of $11.3 \mathrm{~kg} /$ year defined in EPA (1997). Considering the scenario of a lettuce ingestion of $30 \mathrm{~g} /$ person/day from soil B (U concentration levels ranging from 83 to $124 \mu \mathrm{g} / \mathrm{kg}$ fresh weight; Fig. 4) by an adult (60 $\mathrm{kg}$ weight) the estimate $U$ daily intake $\left(\mathrm{DI}_{\text {ing }}\right.$ ) will be 0.04 to $0.06 \mu \mathrm{g} /$ bodyweight day. The estimated concentration for the local inhabitants exposure to $U$ from lettuce ingestion was low and represents only $7 \%$ to $10 \%$ of the TDI $(0.6 \mu \mathrm{g} / \mathrm{kg}$ bodyweight day $)$ recommended by WHO (2004) for ingested uranium. Nevertheless, when a maximum ingestion rate of $22 \mathrm{~kg} /$ year was considered (Hakonson-Hayes et al. 2002) adults will intake up to $20 \%$ of the WHO guideline value. These values could still be higher when lettuce is growing in summer season, as it will be subject to a higher frequency and higher amount of water irrigation.

To evaluate uranium's chemical risk to health an estimate exposure dose must be calculated and compared with the reference dose for chronic oral exposure (3 $\mu \mathrm{g} / \mathrm{kg}$ day) established by EPA since 1989 (IRIS 2007). This reference dose is an estimate of the highest dose that can be taken in every day over a lifetime without causing an adverse health effect. For a realistic health hazard assessment, data of uranium contents for other ingested foodstuffs locally produced and irrigated with local well waters must be available.

\section{Conclusions}

This study provides the first data of soil-water-plant uranium transfer to vegetable foodstuff consuming in the agricultural area surrounding the abandoned uranium mine of Cunha Baixa in order to assess its chemical risk for the local inhabitants. Field experiments carried out with lettuce (Lactuca sativa L.) on soils watered with contaminated and non-contaminated uranium water, in controlled conditions following local
Fig. 4 Uranium concentration in leaves $(\mathrm{mg} / \mathrm{kg}$ dry weight) of lettuce grown on the replicates of plot soils $\mathrm{C}$, $\mathrm{A}$ and $\mathrm{B}$, submitted to different irrigation water quality ( $T W$ Tap water; $N C W$ non-contaminated water and $\mathrm{CW}$ contaminated water)

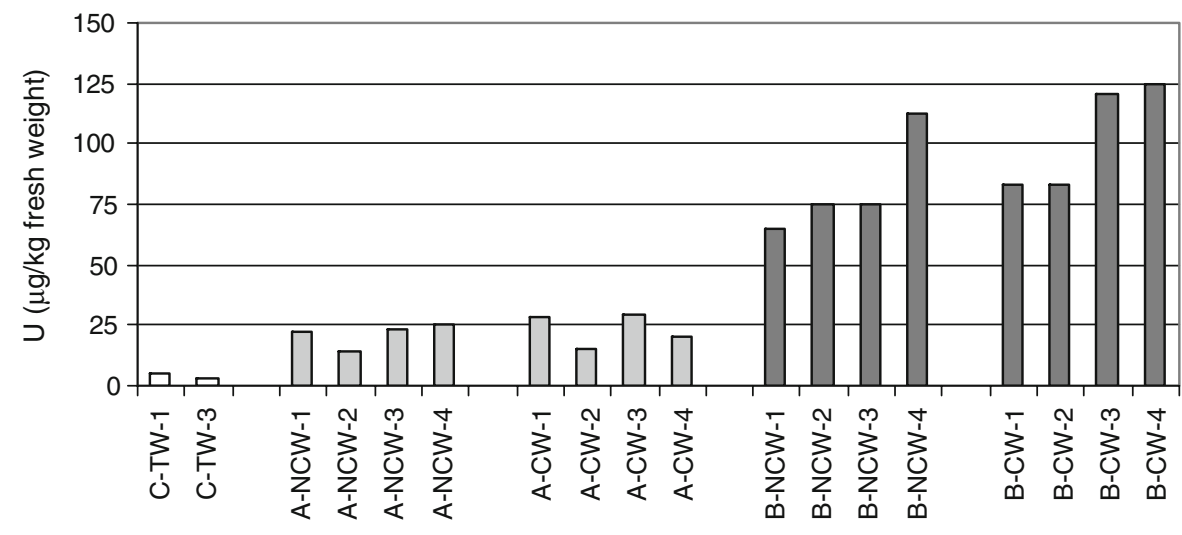

Soil-Irrigation-Replicate 
agricultural practices, have shown that although the plant to accumulates uranium in the roots, it has the capacity to transfer $30 \%$ of the uptake uranium to the edible plant part. The potential risk related to the use of water with different uranium content (contaminated or not contaminated water) for watering the same soil was not significantly different. Uranium speciation seems to be the principal factor that controls uranium lettuce uptake. The highest uranium concentration found in edible lettuce part $(124 \mu \mathrm{g} / \mathrm{kg}$ fresh weight) only account for $10 \%$ to $20 \%$ of the Tolerable Daily Intake. However, the daily consumer of other foodstuff vegetables eventually rich in uranium could represent potential exposure of Cunha Baixa inhabitants to chemical as well as radiological risks that it will be necessary to evaluate in order to protect human health from effects.

Acknowledgments This work has been supported by the Program POCI 2010 and FEDER European Communitarian Funds (Research Project POCI/ECM/59188/2004) and by the Centres of Petrology and Geochemistry and Pedology of Technical University of Lisbon (Portugal).

\section{References}

Abreu, M. M., Tavares, M. T., \& Batista, M. J. (2008). Potential use of Erica andevalensis and Erica australis in phytoremediation of sulphide mine environments: São Domingos, Portugal. Journal of Geochemical Exploration, 96, 210-222.

Actlabs, Activation Laboratories Ltd website: http://www. actalabsint.com.

Alloway, B. J. (1990). Heavy metals in soils. New York: Wiley.

Amrhein, C., Mosher, P. A., \& Brown, A. D. (1993). The effects of redox on Mo, U, B, V, and As solubility in evaporation ponds. Soil Science, 155(4), 249-255.

ANZECC, Australien and New Zealand Environment and Conservation Council (2000). Water Quality Guidelines. Quality for irrigation and general uses. Retrieved March 222007 from http://www.mfe.govt.nz/publications/water/ anzecc-water-quality-guide-02/anzecc-water-qualityguide-02-pdfs.html.

Arnold, E. G., Lenore, S. C., \& Andrew, D. E. (Eds) (1992). Standard methods for the examination of water and wastewater (18th ed.). (APHA).

ATSDR, Agency for Toxic Substances and Disease Registry (1999). Public Health Statement for Uranium. Retrived February 14, 2007 from http://www.atsdr.cdc.gov/tox profiles/phs $150 . h \mathrm{html}$.

Bleise, A., Danesi, P. R., \& Burkart, W. (2002). Properties, use and health effects of depleted uranium (DU): a general overview. Journal Environmental Radioactivity, 64, 93-112.

Carta de Solos (1978). Unidades Pedológicas segundo o esquema da FAO para a Carta dos Solos da Europa (escala
1:1000000). Atlas de Ambiente, Comissão Nacional do Ambiente, Portugal.

DL 236/98, Portuguese Legislation on Water Quality (Decree Law 236/98), DR n ${ }^{\circ}$ 176/98, annexes XVI and XXI.

Duquène, L., Vandenhove, H., Tack, F., Van der Avoort, E., Van Hees, M., \& Wanninj, J. (2006). Plant-induced changes in soil chemistry do not explain differences in uranium transfer. Journal of Environmental Radioactivity, 90, 1-14.

Ebbs, S. D., Brady, D. J., \& Kochian, L. V. (1998). Role of U speciation in the uptake and the translocation of uranium by plants. Journal of Experimental Botany, 49, 11831190.

Egner, H., Riehm, H., \& Domingo, W. R. (1960). Untersuchugen über die chemische bodenanalyses als grundlage für die beurteilung der nahrstoffzustandes der boden. II Chemische extracktions methoden zur phosphor und kaliumbestimmung. Kungliga Lantbrukshoegskolans Annaler, 26, 199215.

EPA, Environmental Protection Agency (1997). Exposure factors handbook. Vol. II. Washington: NCEA.

Fisenne, I. M., Perry, P. M., Decker, K. M., \& Keller, H. K. (1987). The daily intake of ${ }^{234,235,}{ }^{238} \mathrm{U},{ }^{228}, 230,232 \mathrm{Th}$ and 226, 228 Ra by New York City Residents. Health Physics, 53, 357-363.

Fisenne, I. M., Perry, P. M., \& Harley, N. H. (1988). Uranium in humans. Radiation Protection Dosimetry, 24, 127-131.

Foth, H. D. (1990). Fundamentals of soil sciences. New York: Wiley.

Gulati, K. L., Oswall, M. C., \& Nagpaul, K. K. (1980). Assimilation of uranium by wheat and tomato plants. Plant and Soil, 55(1), 55-59.

Hakonson-Hayes, A. C., Fresquez, P. R., \& Whicker, F. W. (2002). Assessing potential risks from exposure to natural uranium in well water. Journal of Environmental Radioactivity, 59, 29-40.

Hayes, A.C., Fresquez, P. R., \& Whicker, W. F. (2000). Uranium uptake study, Nambe, New Mexico: Source document. Technical Report OSTI ID:766753. Los Alamos National Laboratory. Retrieved January 18, 2007, from Energy Citations database.

IAEA, International Atomic Energy Agency (1985). Uranium Biogeochemistry: A bibliography and report on the State of the art, IAEA-TECDOC-327, 9-15.

IAEA, International Atomic Energy Agency (1994). Handbook of parameters values for the prediction of radionuclide transfer in temperate environments. AIEA-Technical Report Series, 364.

IM, Instituto de Metereologia. Boletim Meteorológico para a Agricultura $\mathrm{n}^{\circ}$ 1946-1950. Retrieved October 20, 2007 from http://www.meteo.pt/pt/previsao/inicial.jsp.

INIA, Instituto Nacional de Investigação Agrária-Laboratório Químico Agrícola Rebelo da Silva (2000). Manual de fertilização das culturas.(INIA).

IRIS, Integrated Risk Information System (2007). Uranium, soluble salts. Retrieved October 9, 2007 from http://www. epa.gov/iris/subst/o421.htm.

IWQC, Irrigation Water Quality Criteria G77-328-A (1997). Retrieved February 16, 2002 from http://www.p2pays.org/ ref/20/19718.htm.

Keeney, D. R., \& Nelson, D. W. (1982). Nitrogen-inorganic forms. In A. L. Page, R. H. Miller, \& D. R. Keeney (Eds.), 
Methods of soil analysis (pp. 643-698, 2nd ed.). Madison: Soil Science Society of America.

Lakshmanan, A. R., \& Venkateswarlu, K. S. (1988). Uptake of uranium by vegetables and rice. Water, Air \& Soil Pollution, 38, 1-2 (Online abstract). Retrieved September 9, 2007.

Langmuir, D. (1978). Uranium solution-mineral equilibrium at low temperatures with applications to sedimentary ore deposits. Geochimica Cosmochimica Acta, 42, 547-569.

Laroche, L., Henner, P., Camilleri, V., Morello, M., \& GarnierLaplace, J. (2005). Root uptake of uranium by a higher plant model (Phaseolus vulgaris) - bioavaility from soil solution. Radioprotection, 40(Suppl 1), S33-S39.

Magno, C. E. F. (2001). O sistema de gestão territorial e os recursos geológicos em Portugal. Boletim de Minas, 38(3), 151-160 (Jul/Set).

Meyer, M. C., McLendon, T., \& Price, D. (1998). Evidence of depleted uranium-induce hormesis and differential plant response in three grasses. Journal Plant Nutrition, 21, 2475-2484.

Neves, O. (2002). Minas desactivadas e impactos geoquímicos ambientais. O caso da mina de urânio da Cunha Baixa (Viseu). Ph. D. Dissertation, Technical University of Lisbon, Portugal.

Neves, O., \& Abreu, M. M. (2006). The impact of uranium contaminated water on Latuca Sativa L. grown in soils from Cunha Baixa Mine Area (Portugal). Extended Abstracts Volume 4th Workshop on Hard Rock Hydrologeology of the Bhoemian Massif, June 21-23, 2006, Jugowice, Poland, 43-44.

Neves, O., \& Matias, M. J. (2008). Assessment of groundwater quality and contamination problems ascribed to an abandoned uranium mine (Cunha Baixa region, Central Portugal). Environmental Geology, 53(8), 1799-1810.

Neves, M. O., Matias, M. J., Abreu M. M., Magalhães, M. C. F., \& Basto, M. J. (2005). Abandoned mine site characterization for remediation: the case of the Cunha Baixa uranium mine (Viseu, Portugal). International Workshop on Environmental Contamination from Uranium Production Facilities and their Remediation, IAEA Proceeding Series, 159-169. Retrieved December 10, 2005 from http://www-pub.iaea.org/MTCD/publications/PDF/ Pub1228_web.pdf.

Nriagu, J. O. (1991). Human influence on the global cycling of trace metals. In J. D. Farmer (Ed.), Heavy metals in the environment, Vol. 1. Edinburgh: CEP Consultants.

Parkhurst, D. L. (1995). Users guide to PHREEQC: a computer model to speciation, reaction-path, advective-transport and inverse geochemical calculations. USGS Water-Resources Investigations Report 95-4227.

Póvoas, I., \& Barral, M. F. (1992). Métodos de análise de Solos. Comunicações Instituto de Investigação Científica Tropical. Série Ciências Agrárias, 10, 41-61.

Ribera, D., Labrot, F., Tisnerat, G., \& Narbonne, J. F. (1996). Uranium in the environment: Occurrence, transfer and biological effects. Revue Environmental Contamination and Toxicology, 146, 53-80.

Santos Oliveira, J. M., \& Ávila, P. F. (2001). Geoquímica na área envolvente da mina da Cunha Baixa (Mangualde, no centro de Portugal). Estudos, Notas e Trabalhos, 43, 25-47.
Santos Oliveira, J. M., Canto, M. J., Pedrosa, M. Y., Ávila, P. \& Machado Leite, M. R. (2005). Geochemical evaluation for the site characterization of Cunha Baixa Uranium Mine Central Portugal. International Workshop on Environmental Contamination from Uranium Production Facilities and their Remediation, IAEA Proceeding Series, 233-243. Retrieved December 10, 2005 from http:/www-pub.iaea. org/MTCD/publications/PDF/Pub1228_web.pdf.

Schnug, E., Steckel, H., \& Haneklaus, S. (2005). Contribution of uranium in drinking waters to the daily uranium intake of humans - a case study from Northern Germany. FAL Agricultural Research, 4, 227-236.

Schollenberger, C. J., \& Simon, R. H. (1945). Determination of exchange capacity and exchangeable bases in soil-ammonium acetate method. Soil Science, 59, 13-24.

Shahandeh, H., \& Hossner, L. R. (2002). Role of soil properties in phytoaccumulation of uranium. Water, Air and Soil Pollution, 141, 165-180.

Sheppard, S. C., \& Evenden, W. G. (1988). Critical compilation and review of plant/soil concentration ratios for uranium, thorium and lead. Journal Environmental Radioactivity, 8, 255-285.

Sheppard, S. C., \& Evenden, W. G. (1992). Bioavailability indices for uranium: Effect of concentration in eleven soils. Archives of Environmental Contamination and Toxicology, 23, 117-124 (Online abstract). Retrieved February 16, 2007. 1/July.

Sheppard, S. C., Evenden, W. G., \& Anderson, A. J. (1992). Multiple assays of uranium toxicity in soil. Environmental Toxicology \& Water Quality, 7(3), 275-294.

Sheppard, S. C., Evenden, W. G., \& Pollock, R. J. (1989). Uptake of natural radionuclides by field and garden crops. Canadian Journal Soil Science, 69, 751-767.

Silveira, B. C. (2001). Impacte radiológico da exploração de urânio em Portugal. Geonovas, 15, 71-86.

Singh, K. P. (1997). Uranium uptake by plants. Current Science, 73(6), 532-535.

Srivastava, P. C., \& Gupta, U. C. (1996). Trace elements in crop production. USA: Science.

Vandenhove, H., Van Hees, M., Wannijn, J., Wouters, K., \& Wang, L. (2007). Can we predict uranium bioavailability based on soil parameters? Part 2: soil solution uranium concentration is not a good bioavailability index. Environmental Pollution, 145(2), 577-586.

Walkley, A., \& Black, I. A. (1934). An examination of Degtjareff method for determining soil organic matter and a proposed modification of the chromic acid titration method. Soil Science, 37, 29-38.

WHO, World Health Organization (2001). Depleted uraniumSources, Exposure and Health Effects. WHO/SDE/PHE/01.1 Department of Protection of Human Environment. WHO, Geneva (2001). Retrieved March 20, 2007 from http://www. who.int/ionizing_radiation/pub_meet/ir_pubs/en/.

WHO, World Health Organization (2004). Guidelines for Drinking-water Quality, Uranium, 3rd ed., WHO, Geneva. Retrieved April 16, 2007 from http://www.who.int/water sanitation_health/dwq/en/cmp130704app1.pdf.

Wrenn, M. E., Durbin, P. W., Howard, B., Lipstztein, J., Rundo, J., \& Dill, E. T. (1985). Metabolism of ingested U and Ra. Health Physics, 48, 601-633. 